\title{
MODELLING ANTHROPOMETRY OF TENNIS PLAYERS (AGE 17-18-YEARS)
}

\author{
Rumiana Karapetrova, Georgi Stoykov, Stefan Stoykov \\ National Sports Academy "Vassil Levski"
}

\begin{abstract}
Summary: Tennis is complex sport demanding serious requirements towards the complex development of the player and his training process, including his anthropometry. Everyone who starts to practice tennis goes on the way of the best players. The focus is on their anthropometric, physical and technical abilities. Compliance with this is a guarantee of well-planned selection and training process - guaranteeing a complete sport realization afterwards. The aim of the study is to model the anthropometry of tennis players in the age period 17-18 years. The subject of the study are 30 Bulgarian players (age 17-18 years), ranked among the top 35 in the National rank list. For the purpose of the study are analyzed 14 anthropometry indexes. Results variance suggests that respondents group is homogeneous. All studied indexes are above the average values for this age group in Bulgaria except the weight. On the basis of this analysis we propose a normative table for assessing the level of development of each anthropometric indexes. We recommend as a leading index to differentiate height and weight. Comparing the data of respective training player with those of the elite Bulgarian players in his age group helps us determine the level of development of his anthropometric signs. The proposed evaluation tables provide the opportunity to differentiate the most talented for tennis.
\end{abstract}

Key words: tennis, anthropometry, modelling, physical abilities

\section{Introduction}

Tennis is complex sport demanding serious requirements towards the complex development of the player and his training process, including his anthropometry.

Everyone who starts to practice tennis goes on the way of the best players. The focus is on their anthropometric, physical and technical abilities. Compliance with this is a guarantee of well-planned selection and training process - guaranteeing a complete sport realization afterwards.

Sport selection sets the start of organized sport activities. Some specialists (Shestakov, M, A. Nazarov, I. Mironenko, M. Baibah, H. Jumarov, B. Veshekidze, E. Nazadze - 1989) define it as the most difficult part of the sport theory and methodology.

For M. Buchvarov (2004) the medical and biological characteristics - as height, weight, body structure, functional capacity of cardiovascular system, state of the analyzers - are good prerequisite for "initial selection of candidates for organized sport activities", as well as the selection - selection in the process of preliminary and initial training process".

Wrong selection leads to loss of time for training, traumatization of psyche of young athletes - in practice this is bad promotion of sport itself and for the high-performance sport (Siris, P., P. Gaydarska, Kr. Rachev, 1983; St. Stoykov, 2007).
Great number of sport specialists and coaches examining the problems of sport selection find anthropometrical indexes as height, upper and lower limbs measurements, torso length, chest circumference, shoulder diameter, weight and etc. as such of great importance (Bril, M. 1980; Gujalovskiy, A. 1986; Dorohov, R., V. Guba, V. Petruhin, 1994; Karapetrova, R. 2009; Mos, V. 1976; Penchev, A. 1986; Stoykov, G. 2012; Hem, I. 1976; Durand, P. 1987; Merhautova, I., M. Maček 1966).

Very often in sport practice children who are not noticeable at first glance are overlook at the expense of the children with accelerated growth, with premature development of both anthropometric and motor abilities (Zelenichonok, V., V. Nikityoushin, V. Guba, 2000). Subsequently, it turned out that the first were the future champions. The same authors form the following positions of the sport selection:

1. It is multi-stage process, for long-term period, covering all aspects of the sport training.

2. It is based on the comprehensive study of the capabilities of athletes.

3. Its objectives are to create the most favorable prerequisites for the formation of these abilities as well as their refinement in the chosen sport.

Tz. Jeliazkov (1998) identifies the three main scientific and methodological problems of the sport selection:

1. Morpho-anatomic signs and indicators of 
the health status.

2. Motor abilities - characterizing the genetic capacity of motor and vegetative functions.

3. Psychological signs - intellectual, emotional, etc. Components of the mental status.

Modelling as a main tool for controlling and managing the training process is a way to give more specific attention to the problem of sport selection (Kuznetzov, V. 1975; M. Buchvarov, 1991).

In our case, we apply modeling to develop models regarding anthropometric characteristics of young tennis players at certain stage of their development - the age period 17-18-years.

\section{Aim and Objectives of the study}

The aim of the study is to model the anthropometry of tennis players in the age period 17-18 years. The subject of the study are 30 Bulgarian players (age 17-18 years), ranked among the top 35 in the $\mathrm{Na}$ tional rank list.

\section{Methods}

For the purpose of the study are analyzed 14 anthropometry indexes (see Table 1). All gathered research data was analyzed using variance analysis (applying SPSS computer software). Based on the results of the variance analysis, using sigmal method we developed evaluation tables for assessment of anthropometric indexes.

Table 1

Anthropometric indexes.

\begin{tabular}{|c|c|c|c|}
\hline signature & name of the index & measured in: & accuracy \\
\hline X1 & Height & $\mathrm{cm}$ & 1 \\
\hline X2 & Weight & $\mathrm{kg}$ & 1 \\
\hline X3 & Upper limbs combined length & $\mathrm{cm}$ & 1 \\
\hline X4 & Upper limb length & $\mathrm{cm}$ & 1 \\
\hline X5 & Armpit length & $\mathrm{cm}$ & 1 \\
\hline X6 & Forearm length & $\mathrm{cm}$ & 1 \\
\hline X7 & Lower limb length & $\mathrm{cm}$ & 1 \\
\hline X8 & Thigh length & $\mathrm{cm}$ & 1 \\
\hline X9 & Shank length & $\mathrm{cm}$ & 1 \\
\hline X10 & Torso length & $\mathrm{cm}$ & 1 \\
\hline X11 & Foot length & $\mathrm{cm}$ & 1 \\
\hline X12 & Shoulder diameter & $\mathrm{cm}$ & 1 \\
\hline X13 & Playing armpit circumference & $\mathrm{cm}$ & 1 \\
\hline X14 & Non-playing armpit circumference & 1 \\
\hline
\end{tabular}

Explanation: The length of the forearm includes the length of the hand; the length of the shank includes the length of the foot.

\section{Results analysis}

Table 2 presents the variance analysis of the research data for the age period 17-18-years.

Table 2

Variance analysis.

\begin{tabular}{|c|c|c|c|c|c|c|c|c|c|c|}
\hline signature & $\mathrm{X}$ & $\pm \mathrm{Mx}$ & $\mathrm{S}$ & $\mathrm{Ex}$ & $\mathrm{As}$ & $\mathrm{R}$ & $\mathrm{Min}$ & $\mathrm{Max}$ & $\mathrm{N}$ & $\mathrm{V} \%$ \\
\hline $\mathrm{X} 1$ & 180,92 & 0,64 & 3,12 & $-0,51$ & $-0,56$ & 12 & 174 & 186 & 24 & 1,72 \\
\hline $\mathrm{X} 2$ & 72,29 & 0,92 & 4,51 & 0 & 0,12 & 18 & 63 & 81 & 24 & 6,23 \\
\hline $\mathrm{X} 3$ & 182,29 & 0,94 & 4,59 & 1,13 & 1 & 18 & 177 & 195 & 24 & 2,52 \\
\hline $\mathrm{X} 4$ & 80,88 & 0,49 & 2,38 & $-1,3$ & $-0,11$ & 7 & 77 & 84 & 24 & 2,95 \\
\hline $\mathrm{X} 5$ & 33,96 & 0,29 & 1,43 & $-1,34$ & $-0,02$ & 4 & 30 & 37 & 24 & 4,47 \\
\hline $\mathrm{X} 6$ & 48,67 & 0,55 & 2,68 & 0,6 & $-0,75$ & 12 & 42 & 54 & 24 & 5,51 \\
\hline $\mathrm{X} 7$ & 103,79 & 0,47 & 2,32 & $-0,87$ & 0,07 & 8 & 100 & 108 & 24 & 2,24 \\
\hline $\mathrm{X} 8$ & 47,96 & 0,48 & 2,33 & $-0,49$ & 0,3 & 9 & 44 & 53 & 24 & 4,86 \\
\hline $\mathrm{X} 9$ & 55,79 & 0,58 & 2,83 & 1,08 & $-1,33$ & 13 & 47 & 60 & 24 & 5,07 \\
\hline $\mathrm{X} 10$ & 55,54 & 0,51 & 2,52 & 2,25 & 1,17 & 10 & 52 & 62 & 24 & 4,54 \\
\hline $\mathrm{X} 11$ & 29,54 & 0,07 & 0,33 & $-0,42$ & $-0,08$ & 1 & 29 & 30 & 24 & 1,11 \\
\hline $\mathrm{X} 12$ & 44,38 & 0,31 & 1,5 & 1,14 & 0,73 & 7 & 41 & 48 & 24 & 3,38 \\
\hline $\mathrm{X} 13$ & 29,33 & 0,37 & 1,83 & $-0,19$ & $-0,26$ & 7 & 25 & 32 & 24 & 6,25 \\
\hline $\mathrm{X} 14$ & 27,54 & 0,38 & 1,86 & $-1,09$ & $-0,18$ & 6 & 24 & 30 & 24 & 6,77 \\
\hline
\end{tabular}


The height (X1) has average value of $180,92 \mathrm{~cm}$, with relatively wide range $(\mathrm{R})-\mathrm{X} \min$ is $174 \mathrm{~cm}$, and $\mathrm{Xmax}$ $-186 \mathrm{~cm}$. The results show higher level compared to the average values for this age period in Bulgaria.

Weight (X2) vary between 63 and $81 \mathrm{~kg}$ (average values is $72,29 \mathrm{~kg}$ ).

Upper limbs combined length (X3) has average value slightly above the average height $(178,63 \mathrm{~cm})$, ranging from 157 to $186 \mathrm{~cm}$.

The length of the upper limb (X4), armpit (X5) and forearm (X6) show values that can only be ascertained, due to the fact that we do not have similar data and age period to compare with. The same is valid for the lower limb length (X7), thigh (X8) and shank (X9).

The torso length (X10) has average value of 55,54 $\mathrm{cm}$, ranging from $52 \mathrm{~cm}$ to $62 \mathrm{~cm}$.

The respondents foot length (X11) varies between
29 and $30 \mathrm{~cm}$, with average value of $29,54 \mathrm{~cm}$.

The shoulder diameter (X12) has wide range from $41 \mathrm{~cm}$ to $48 \mathrm{~cm}$, average value is $44,38 \mathrm{~cm}$.

High circumference we find in the paying armpit (X13) compared to the non-playing armpit (X14) $29,33 \mathrm{~cm}$ vs. $27,54 \mathrm{~cm}$.

Results variance suggests that respondents group is homogeneous. All studied indexes are above the average values for this age group in Bulgaria except the weight.

On the basis of this analysis we propose a normative table for assessing the level of development of each anthropometric index. We recommend as leading indexes to differentiate height and weight.

The numerical and verbal expression of the assessment is as follows: very high (6), high (5), good (4), average (3) and below average (2).

Table 3

Studied indexes assessment table.

\begin{tabular}{|l|l|l|l|l|l|}
\hline \multicolumn{1}{|c|}{ index } & \multicolumn{1}{c|}{2} & \multicolumn{1}{c|}{3} & \multicolumn{1}{c|}{4} & \multicolumn{1}{c|}{5} & \multicolumn{1}{c|}{6} \\
\hline Height $(\mathrm{cm})$ & under 175 & $175-177$ & $178-183$ & $184-187$ & over 187 \\
\hline Weight $(\mathrm{kg})$ & under 63 & $63-67$ & $68-76$ & $77-81$ & over 81 \\
\hline Upper limbs combined length $(\mathrm{cm})$ & under 173 & $173-177$ & $178-186$ & $187-191$ & over 191 \\
\hline Upper limb length $(\mathrm{cm})$ & under 76 & $76-77$ & $78-84$ & $85-86$ & over 86 \\
\hline Armpit length $(\mathrm{cm})$ & under 29 & $29-30$ & $31-33$ & $34-35$ & over 35 \\
\hline Forearm length $(\mathrm{cm})$ & under 43 & $43-45$ & $46-51$ & $52-54$ & over 54 \\
\hline Lower limb length $(\mathrm{cm})$ & under 99 & $99-100$ & $101-106$ & $107-108$ & over 108 \\
\hline Thigh length $(\mathrm{cm})$ & under 43 & $43-45$ & $46-50$ & $51-53$ & over 53 \\
\hline Shank length $(\mathrm{cm})$ & under 50 & $50-52$ & $53-58$ & $59-61$ & over 61 \\
\hline Torso length $(\mathrm{cm})$ & under 51 & $51-52$ & $53-57$ & $58-61$ & over 61 \\
\hline Foot length $(\mathrm{cm})$ & under 29 & $29-29,5$ & $30-30,5$ & $30,5-31$ & over 31 \\
\hline Shoulder diameter $(\mathrm{cm})$ & under 41 & $41-42$ & $43-45$ & $46-47$ & over 47 \\
\hline Playing armpit circumference $(\mathrm{cm})$ & under 26 & $26-27$ & $28-30$ & $31-32$ & over 33 \\
\hline Non-playing armpit circumference $(\mathrm{cm})$ & under 24 & $24-25$ & $26-28$ & $29-30$ & over 31 \\
\hline
\end{tabular}

\section{Conclusion}

Comparing the data of respective training player with those of the elite Bulgarian players in his age group helps us determine the level of development of his anthropometric signs. The proposed evaluation tables provide the opportunity to differentiate the most talented for tennis.

Subsequent findings based on study results can be a basis for making adjustments to the construction and planning of the training process.

\section{References}

Durand, P, (1987) - L,enfan et le sport, Press Universitaires oe France.

Bril, M, (1980) - Otbor v sportivnykh igrakh, FiS, M.

Buchvarov, M, (2003) - Sporttologiya, S.

Velchev, L, (1997) - Haide da igraem tenis, S. 
Dimov, Iv, (1994) - Optimizirana metodika za podgotovka na visokokvalifitsirani tenisisti, Disertatsiya, NSA, S. Zakharieva, Tsv, (2008) - Disertatsiya, NSA.

Zelenichonok, V., V. Nikityoushin, V. Guba (2000.) Legkaya atletika, Kriterii otbora, M,

Mos, V, (1976) - Otkrivaneto na talanti i nasŭrchavaneto im da ostanat v tenisa, Met, pomagalo, BFT, S.

Penchev, A, (1986) - Edinna programa za obuchenie i trenirovka po tenis, $\mathrm{S}$.

Todorov, T, (1998) - Fizichesko podgotovka na sŭstezatel po tenis ot naĩ-ranna do mladezhka vŭzrast, (7 - 17 godini), S.

Hem, I, (1976) - Belezhki po problema za otkrivane na talantite $\mathrm{v}$ tenisa, BFT, $\mathrm{S}$.

\section{Author information:}

Senior lecturer Rumyana Karapetrova, PhD, National Sports Academy "Vassil Levski", Department “Track \& Field"

Address: Sofia, Bulgaria, ZIP 1700, "Studentski gard", NSA “Vassil Levski”, (Department "Track \& Field”)

Mobile+359 892299 866, e-mail: rumyanakar@abv.bg 